\title{
An Information Architect's Approach to Address Indian Farmers' Indebtedness
}

\author{
Pranab Das \\ Principal Architect, Monocept \\ Cyber Pearl, Hitech City \\ Hyderabad, India
}

\author{
Abhinav Das \\ Student, Manipal University Jaipur \\ Dehmi Kalan, Sanganer \\ Jaipur, Rajasthan, India
}

\begin{abstract}
The Indian farmer, including their counterparts in some developed countries, fell in debt-trap even as GDP and food prices soared and many sectors of the economy shared benefits of GDP growth. Apparently, none of the systemscolonial, socialist, or market-based-have tools to share economic prosperity with the farmer ${ }^{1}$. The paper simulates steps in order to experimentally demonstrate that there could be very high risk in agricultural production. Finally, it proceeds to outline architecture of a centralized digital market, different from existing forms of markets available to the farmer, which addresses such risk as is associated with payoff from agriculture.
\end{abstract}

\section{General Terms}

Pearson $r$ : Pearson $r$ coefficient determines correlation between two data series, which can be positive or negative depending on whether both series increase or decrease together or one increases while the other decreases. A lower or higher absolute value of $r$ indicates weaker or stronger correlation respectively. Also, vide footnote 5 .

Bid: $\mathrm{Bid}^{2}$ is defined as an amount offered as price to buy a product in the production plan of the farmer. Generally, bids are associated with conditions, period of validity being an important one. Bidders would overbid one another in a competitive market until a plateau is reached. The farmer would typically wait until prices become stable. Bids may follow the pattern of English Auction [8].

Ask: Ask is an amount quoted as price to sell a factor in the production plan of the farmer. In a competitive market, askers would tend to offer lower and lower prices for a factor until a stability is attained. Asks may follow the pattern of Dutch Auction [9], [10].

Hedging: Hedging would be construed to mean a mechanism that ensures that costs of factors and prices of products do not change after production. This is partially satisfied by the amount of loan provided by the middleman since such amount serves as the minimum guaranteed price of products. For other definitions of hedging vide [11], [12].

Monopoly and monopsony: If a market has only one seller or

\footnotetext{
${ }^{1}$ Even though India's share of world GDP was 22.6 percent in 1700, marginally less than Europe's share of 23.3 percent [1], the farmer used to be oppressed by the then prevailing colonial policies such as high rent even during the great depression [2], which occasionally turned them rebellious [3].

Preobrazhensky, the socialist theoretician promulgated, "it would be necessary to exact 'tribute' from the peasantry to pay for industrialization, largely by turning the terms of trade against the rural sector," [4] famously known as the Price Scissors [5]

Lacuna of market-economy in infusing competition into agricultural factor and product markets is discussed later in the paper.

${ }^{2}$ The definition has been customized [6], [7]; similarly for some other terms.
}

buyer of a good then such market would be termed as monopoly or monopsony respectively. Oligopoly or oligopsony have been covered under these definitions. Thus, if there are two sugar mills in a village, they would rarely offer any competition. Monopsonistic competition may be observed in having a sugar mill and a rice mill in a village. However, once the farmer is committed, the market falls back to monopsony [13]-[15].

Auction: Auction [6]-[8], [16] mentioned here or reverse auction below would be conducted via a web portal. Anyone with internet connectivity or even a phone-through a teleportal service - should be able to connect to auction or reverse auction service, provided one is a member of the FE (Farmers' Exchange). Other means of participation to the portal may be devised to extend its reach further. Banks and post offices may play important role in handholding and popularizing the service.

Auction is meant for bidding for products, vide above.

Reverse auction: Reverse auction [17] is meant for asking for factors, vide above. It is carried out at the same portal, at the same time, and with the same set of production plans.

\section{Keywords}

Digital exchange, electronic exchange, auction, reverse auction, agriculture, middleman, commodity market, agricultural economics

\section{INTRODUCTION}

That the Indian farmer has been reeling under debt may be surmised from a report [18] that says that one farmer committed suicide in India every 32 minutes between 1997 and 2005 , taking the toll to about 100,000 lives, $86.5 \%$ of whom were under debt trap. Interestingly, even though less severe, a similar fate awaited their counterparts in some developed countries - in Midwest, US, rate of suicide amongst male farmers was twice that of general populace whereas it was one per week in $\mathrm{UK}^{3}[18]$.

Data collected by the National Sample Survey Organization (NSSO) of India suggest that higher return from agriculture would help the situation.

\footnotetext{
${ }^{3}$ Empirical evidence suggests that adverse economic condition may lead to delinquency and suicide [19] [20] [21].
} 


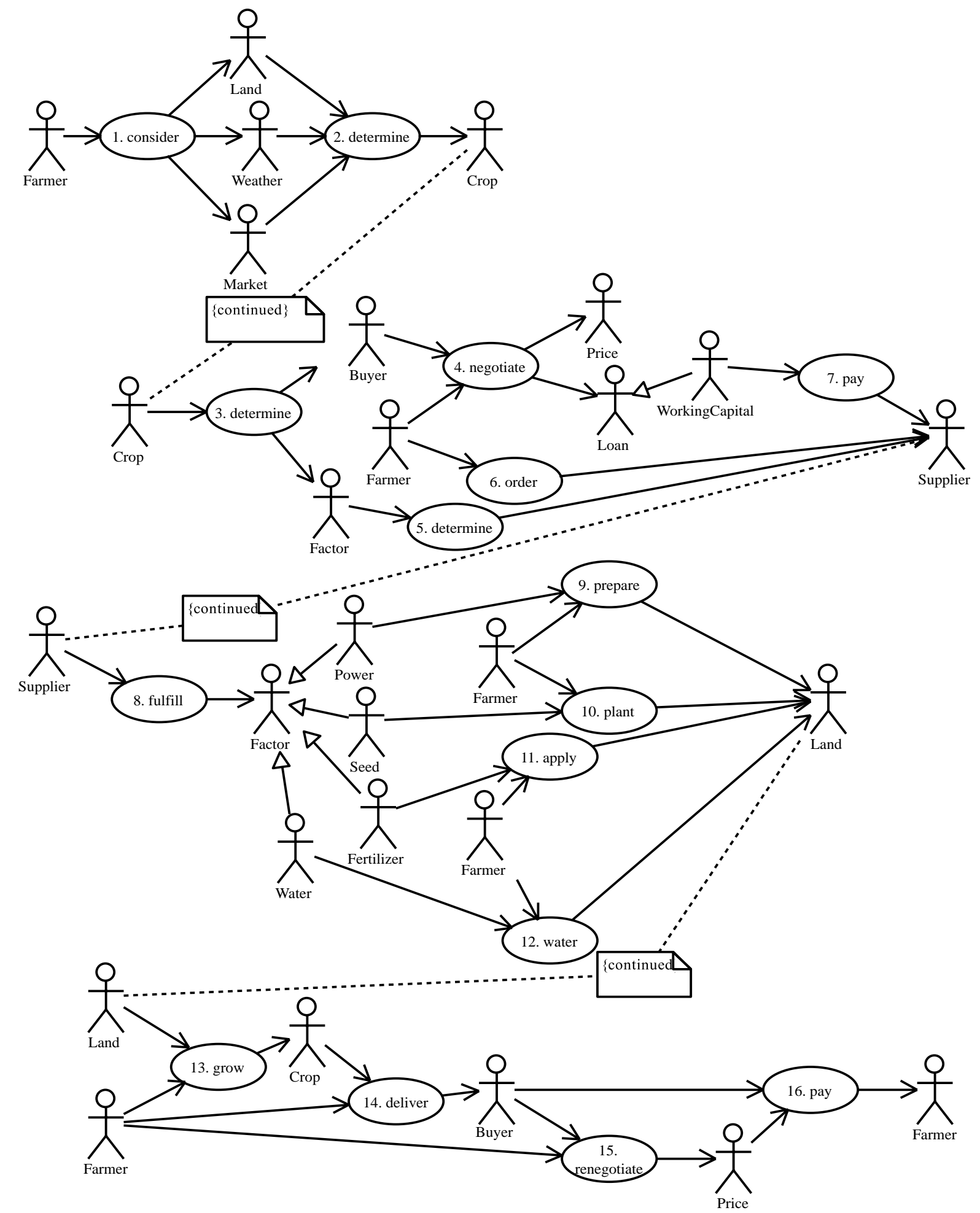

Figure 1: A sample workflow of Indian agriculture

2. Figures ${ }^{4}$ in Error! Not a valid bookmark self-reference. have been computed from a secondary source [22] based on sample

\footnotetext{
${ }^{4}$ Humanoid figures represent "actors", ellipses "use cases", arrows "directed associations", and triangle-head-arrows "extension" [29]. Dog-ear rectangles contain notes in braces while dotted lines anchor them to other elements. Names of actors are capitalized-upper "camel case"- and names of use cases starts with lower case-lower "camel-case" [30].
}

survey conducted by NSSO in 2003. According to the table, the larger the share of income from agriculture is, the lower the incidence of indebtedness of the farmer could be ${ }^{5}$. Even though extent of

\footnotetext{
5 'Could be' is used to indicate weak correlation, 'does not depend on' for negligible correlation, and 'would' for strong correlation [23].
} 
indebtedness does not, apparently, depend on $^{5}$ agriculture being source of income, higher returns from agriculture would ${ }^{5}$ APPENDI.

Table 1. Pearson's $r$ coefficient between concept-pairs

\begin{tabular}{lcc}
\hline & $\begin{array}{l}\text { Share of annual } \\
\text { income from } \\
\text { agriculture }\end{array}$ & $\begin{array}{l}\text { Return from } \\
\text { agriculture }\end{array}$ \\
\hline $\begin{array}{l}\text { Incidence of } \\
\text { Indebtedness }\end{array}$ & $-29 \%$ & $-69 \%$ \\
$\begin{array}{l}\text { Extent of } \\
\text { Indebtedness }\end{array}$ & $-9 \%$ & $-45 \%$ \\
\hline
\end{tabular}

\section{MIDDLEMAN}

Nature of the middleman of India has been described by many [24]-[28]. The paper will assume that the middleman are private monopolists or monopsonists that act as the buyer of farm products, the seller of factors, or the lender of capital ${ }^{6}$. One-off sugar mills or rice mills in villages are examples of middlemen. They often agree with the farmer to buy their products. However, generally, their rates are not competitive. Further, they often deprive the farmer of initially agreed price on some pretext or other ${ }^{7}$. Similarly, there would be not many factor-suppliers in a village. Typically, the buyers would advance loan to the farmer that could fulfill their working capital requirements. It is presumed that the farmer would have practically little or no access to competitive markets because theaters of Indian agriculture are villages that are remote.

The Panchayat Raj Government had decided [31] to create physical markets where the farmer could sell their products directly to the end consumer. However, five years after such decision, in a report to the Mumbai High Court, an independent organization [32] submitted that ground realities did not change much in Maharashtra, a state with high incidence of suicide amongst farmers.

\section{AN EXPERIMENT WITH SIMULATED STEPS}

The use case diagram [29] in Figure 1 represents a workflow of agricultural production with simulated steps. Notably, no system boundary exists between the business and the information systems. The workflow begins and ends with the farmer since its purpose was to model allocative cycles of production related to payback from agriculture. Repetitions were meant to unclutter the diagram. Use case numbering was used to indicate order or timing ${ }^{8}$ of steps.

The workflow begins with the farmer considering land, weather, and market to determine crop. They may consider a different set of inputs or, if a set of considerations cannot narrow down their choice sufficiently then they may consider more or different set of considerations.

In the model it is assumed that there would be one buyer for

\footnotetext{
${ }^{6}$ Sometimes oligopoly, oligopsony, monopolistic competition, or monopsonistic competition may be present instead: absence of fair competition is assumed to be a fundamental characteristic of the middleman-dominated Indian agriculture market.

${ }^{7}$ In authors' experience, a sugar mill did not allow delivery of sugarcane until the latter was bone-dry that caused considerable weight-loss due to evaporation of water while retaining sucrose content.

${ }^{8}$ The scheme is borrowed from how risk is measured in projects [33].
}

\section{reduce both incidence and extent of indebtedness. For elaboration, vide}

the single crop produced and one supplier for all factors. After selecting crop, the farmer and the buyer would negotiate price of production and amount of loan. Loan would be utilized to pay for factors. After the supplier fulfills, the farmer would prepare land for cultivation and proceed to grow crop. This will be followed by delivery of crop to the buyer, who would renegotiate to pull down the price further and finally pay the balance amount, if any, to the farmer.

Table 2. Stochastic relationship between process quality and goal

\begin{tabular}{ccc}
\hline Process quality $^{9}$ & $\chi$ & $\chi^{213}$ \\
\hline $2 \sigma=\bar{x} \pm 2 s$ & 0.954499736 & 0.000049232 \\
$3 \sigma=\bar{x} \pm 3 s$ & 0.997300204 & 0.562235640 \\
$4 \sigma=\bar{x} \pm 4 s$ & 0.999936658 & 0.986598238 \\
$5 \sigma=\bar{x} \pm 5 s$ & 0.999999427 & 0.999877894 \\
$6 \sigma=\bar{x} \pm 6 s$ & 0.999999998 & 0.999999580 \\
\hline
\end{tabular}

Assuming that the goal of the above workflow is a predetermined (fixed) return to the farmer, each step may contribute to such goal. It is argued that outcome of each step is determined by a stochastic process and not a deterministic one [35]. It can be shown that if each step has probability ${ }^{10} \chi$ of positively contributing to the goal then probability of realizing such goal would be $\chi^{213}$ vide Error! Reference source not found. Error! Reference source not found. gives an idea of risky nature of reaching the goal of fixed returns under influence of the middleman - even with uniform process quality as high as $2 \sigma$, i.e. 95.5 percent, there is practically no chance -5 in 100,000 - of predetermined returns to the farmer.

\section{ADVANTAGES OF THE MIDDLEMAN TO THE FARMER}

Before proceeding to design an alternative to the middleman, it is important to specify unique advantages of the middleman to the farmer that are not offered by any other infrastructure.

\subsection{Ubiquity}

The middleman is available to cater to needs of the farmer even at remote villages.

\subsection{Easy Loan}

The middleman advances the farmer loan against their crop. Even if terms of such loan are unfavorable compared to institutional ones, associated formalities are, generally, much simpler.

\subsection{Local delivery}

The farmer need not plan logistics of transportation over long distances since buyers and suppliers would be local.

\subsection{Hedging}

The amount of advance paid by the buyer to the farmer serves as amount guaranteed against the harvest-to-be.

\section{AVAILABLE ALTERNATIVES TO}

\footnotetext{
${ }^{9} \bar{x}$ and $s$ were taken to be the sample mean and sample standard deviation, respectively [34].

${ }^{10}$ Probabilities must be a fraction between 0 and 1 ; hence, $0 \leq \chi \leq 1$.
} 


\section{THE MIDDLEMAN}

It may be mentioned that markets organized by the Panchayat Raj Government, as a substitute to the middleman, are not ubiquitous, nor do they meet working capital requirements of the farmer. Logistics associated with transportation of products to those markets could be a deterrent. Lastly, they cannot hedge production. Again, commodity markets in general and those of India [37] in particular are not designed for physical delivery of products-participants in such markets predominantly trade instruments. Further, it would be difficult for the farmer to carry their products to designated warehouses that commodity markets require. Lastly, they do not ease the process of raising a loan towards working capital. Still, they may hedge products.

Considering the above, an electronic marketplace with the following characteristics has been designed as a substitute for the middleman.

\section{FARMERS' EXCHANGE (FE)}

FE is visualized as an alternative to the middleman that imitates its unique advantages while minimizing risks associated with return to the farmer under such system.

\subsection{Ubiquity}

FE would be a ubiquitous digital exchange. It ought to be available in remotest of villages via data and voice networking channels, both. Modern technology allows conversion of one of these to the other, via speech decoding or synthesis. Secondly, it should be accessible to even small and marginal farmers-price of accessing FE may not pose a deterrent. Thirdly, the user may not be forced to acquire new skills to operate $\mathrm{FE}$ - it may depend on natural acquisition such as mother tongue of the user. Speech decoding and synthesis or call centers with multilingual live agents may enable the FE.

\subsection{Workflows}

It is assumed that FE would allow three classes of operatorsfarmers, buyers, and suppliers - who are to be called players. They would participate in the following workflows managed by FE vide Error! Reference source not found.. Even though the system has been depicted as fragments of workflows, they are to be parts of one and the same centralized FE.

\subsubsection{Registration}

A player should be registered with FE in order to participate in any other workflow.

It starts with a request for registration accompanied by a surety. Surety is designed to allow FE recover workflows left in limbo due to non-performance by one or more players. Thus, e.g. if the buyer in a contract fails to take delivery, services of an auctioneer may be called in to sell products at spot prices. In such case surety would be utilized to pay for the difference between exercise and spot prices. Thus, surety would be related to the risk of performance of the concerned player.

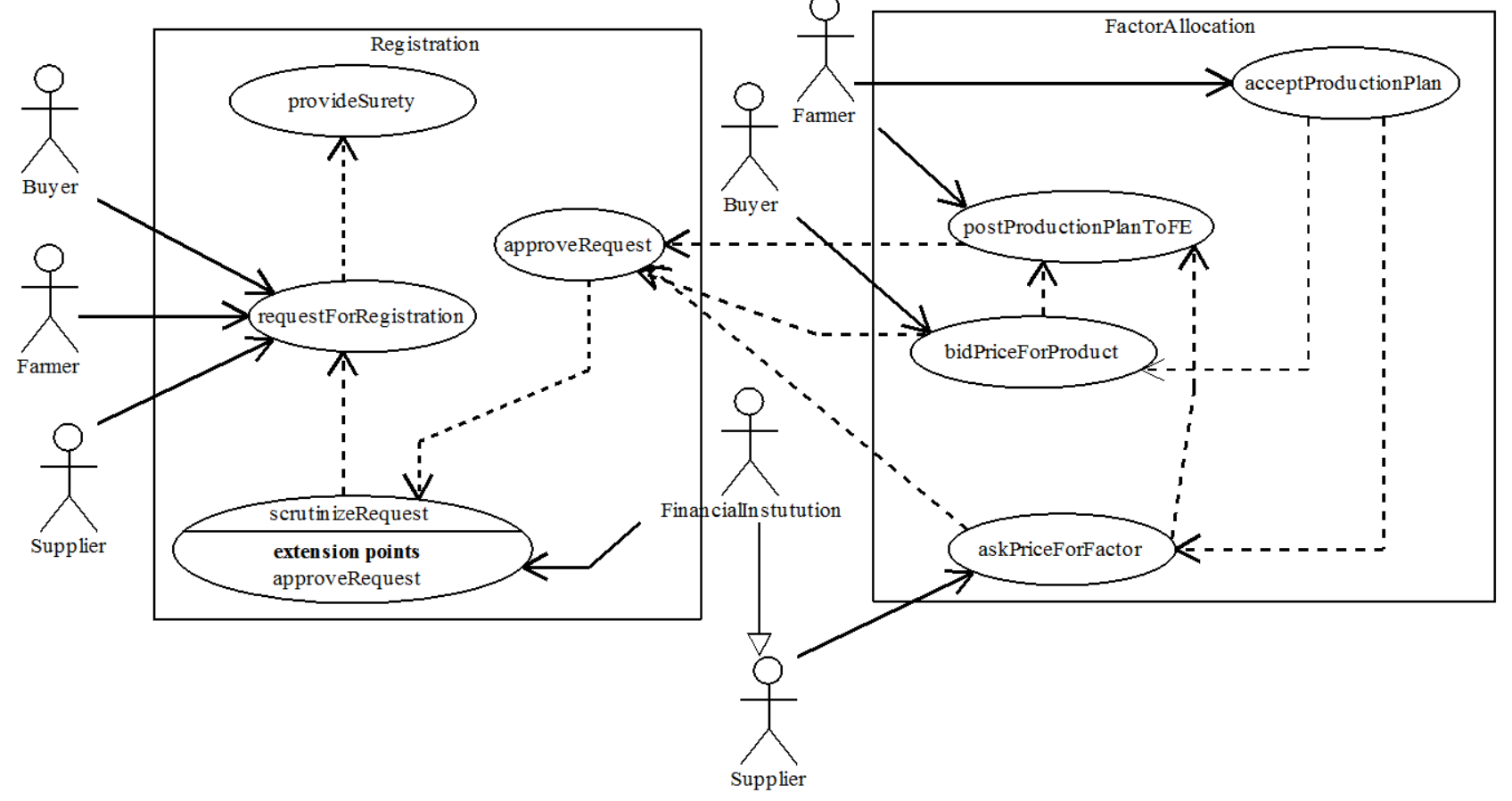

Figure 2: FE workflows-registration and factor allocation ${ }^{11}$

\footnotetext{
${ }^{11}$ For definition of symbols, vide footnote Error! Bookmark not defined.. Dotted arrows indicate dependency of the source on the destination. Boxenclosures would normally related to systems. However, here, they were used to denote logical subdivision of systems into workflows.
} 
Financial institutions, which constitute a class of suppliers that manage financial transactions, may act as agents of FEimplement the registration facet of FE-by allowing players to register through them. Also, see Error! Reference source not found..

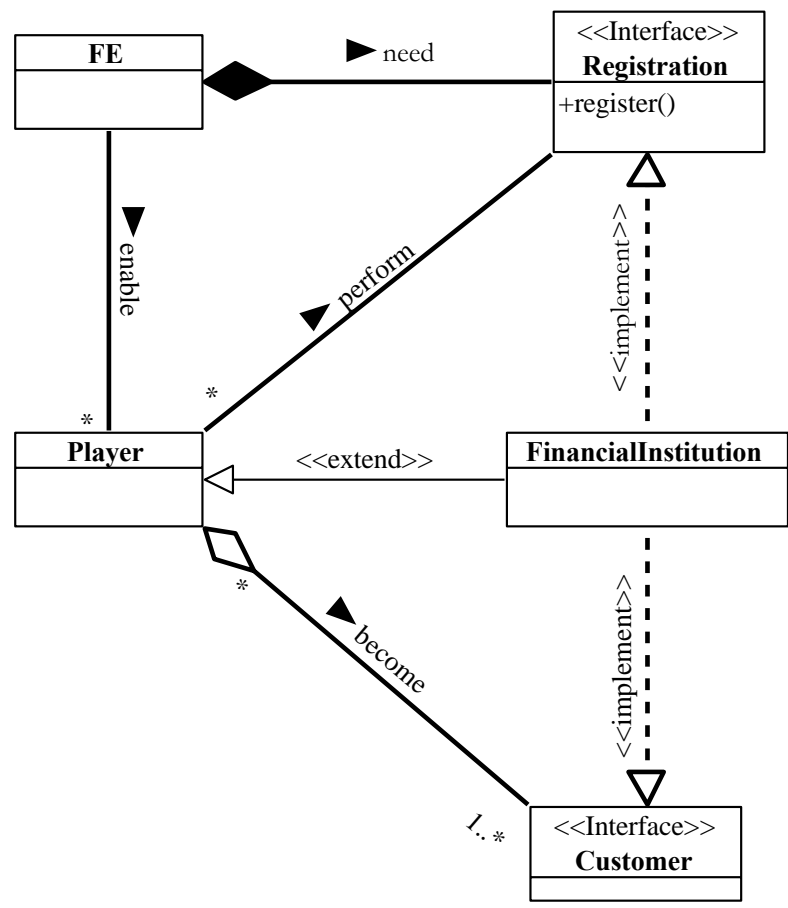

Figure 3: UML class diagram for registration

\subsubsection{Allocation of goods}

The process would start with the farmer posting one or more production plan, which is a vector of goods. Such goods as act ingredients of production (factors), would be distinguished by a negative sign. Others that are produced from production (products) would bear no sign. Position or order of a good in a production plan would be mapped to its type or nature and the scalar value to its quantity expressed as cost (of a factor) or price (of a product).

$$
\rho=\left(-g_{1}, \ldots,-g_{m}, g_{m+1}, \ldots, g_{m+n}\right)
$$

Thus, $\rho$ in (1) above represents a production plan with $m$ factors and $n$ products. Absolute value of the scalar $g_{j}$ would give cost or price of $g_{j}$ for all $j$ in $\{1, \ldots, m+n\}$. Vide Error! Reference source not found., the farmer would post their production plans for other players of FE to offer bid (by buyers) or ask (by suppliers). Bids would typically follow the pattern of English Auction [38], i.e. starting with a lower price that is progressively raised. Ask would follow the pattern of Classic Dutch Auction [9] that starts with a higher price, which is progressively lowered. The farmer may accept a production plan that would close a contract involving all bidders and askers. Generally, it would happen when all goods are covered and the farmer considers they have enough spread, vide (2) below.

$$
\pi(\rho)=\sum_{j=1}^{m+1} g_{j}=-\sum_{j=1}^{m}\left|g_{j}\right|+\sum_{j=m+1}^{n}\left|g_{j}\right|
$$

$\pi(\rho)$ in (2) above denotes spread, which is signed aggregate of all goods in the production plan $\rho$. Here, spread signifies contractual net payoff to the farmer from a production plan.

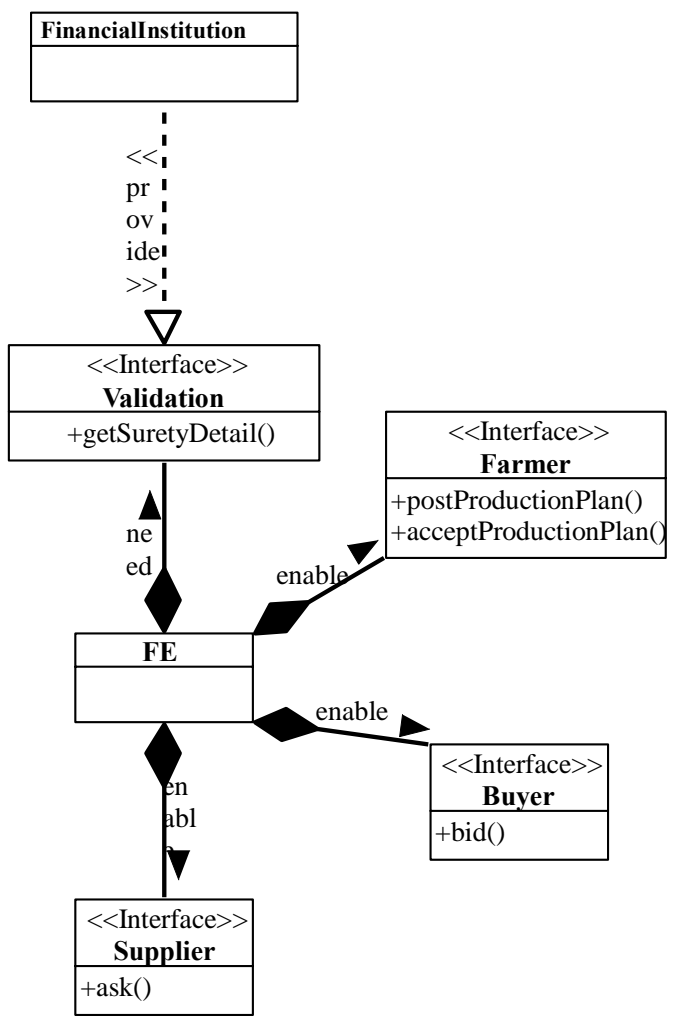

Figure 4: Factor allocation interfaces of FE

FE would verify, inter alia, that a player provides sufficient surety to cover failure to fulfill one's commitment to other parties to a contract. Amount of such surety may be determined by a margin, which is being defined as the premium necessary to induct an emergency player in place of a regular participant to a contract, when failure of the latter is imminent. Thus, for example, if the buyer fails to receive delivery of a product, an auctioneer may be asked to sell the same by auction, where margin $m$ would be given by

$$
m=e-s+x
$$

where $e$ is the exercise price, $s$ spot price, and $x$ is the aggregate of all expenses and profits payable to the auctioneer. The margin may vary depending on various parameters. It is apparent that redundant players are necessary to provide resilience to contracts

\subsubsection{Production}




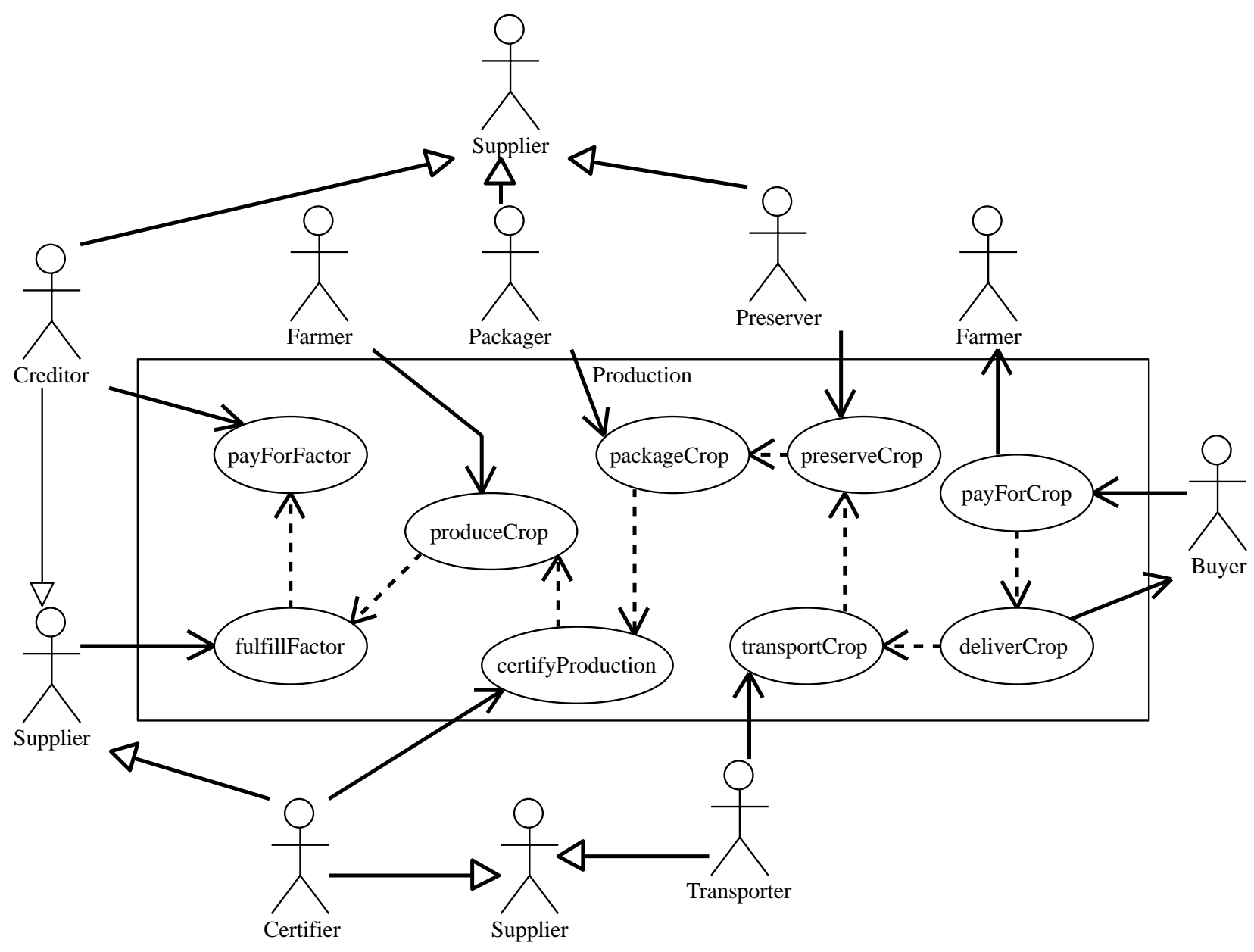

Figure 5: FE Workflow-Production

Table 3. Pre-production financial accounting ${ }^{12}$

(All dates are pre-production)

FI* of Creditor

To Creditor

(Being price of factors $x$ withdrawn from creditor's a/c.)

FI of Supplier ${ }^{13}$

To FI of Creditor

\begin{tabular}{l|c|c} 
& $D r$. & $C r$. \\
Dr. & $x$ & \\
& & $x$
\end{tabular}

Cr.

(1)

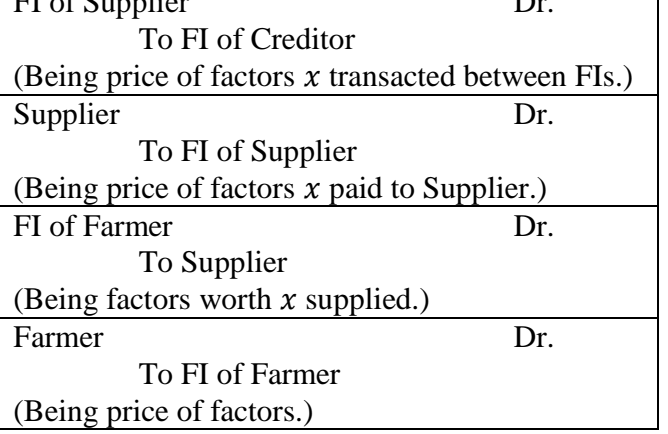

\section{(*) FI = Financial Institution}

Once a contract is closed, the creditor's account would be automatically debited and suppliers' account credited

\footnotetext{
${ }^{12}$ For description of double-entry book keeping style, standard books on financial accounting may be referred [39].

${ }^{13}$ For simplicity, a generic supplier is considered here. In reality, all classes of suppliers, e.g. seed, water, fertilizer, etc. would replace supplier. Creditor is also a supplier, who should be paid interest.
}

triggering fulfillment of factors by the latter. In financial accounting terms the transactions would be following.

\section{Table 4. Post-production financial accounting}

(All dates are post-production) Buyer

$$
\begin{array}{c|c|c} 
& \text { Dr. } & C r . \\
\text { Dr. } & y & \\
& & y
\end{array}
$$$$
\text { To FI of Buyer }
$$

(Being agreed price $y$ of duly certified and packaged crop upon delivery through designated transporter or preserver.)

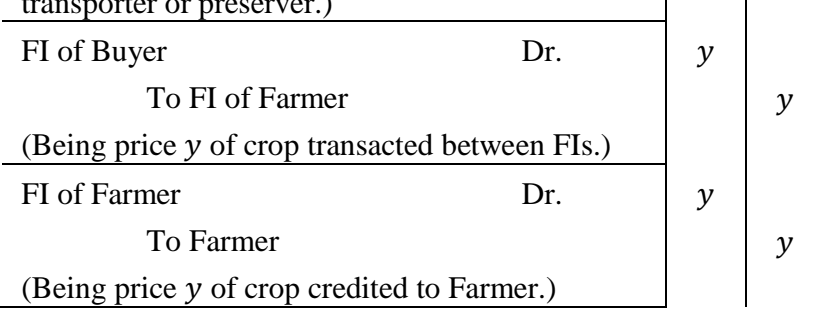

Instead of direct transaction, electronic credit would take place through financial institutions representing players, thereby bringing in more transparency. After the farmer produces crop, other categories of suppliers such as certifiers, packagers, preservers, and transporters would play their roles. After delivery through transporters is confirmed, the buyer's account would be automatically debited and the farmer's account credited. Here, again, all outstanding loans and charges would be deducted in order to calculate the net 
amount due to the farmer.

\subsection{Interest on credit}

When a contract is closed, FE would invoke the creditor with request for credit, vide Figure 6 . The creditor is also a supplier and would be selected from among competitors on the basis of low interest rates and other conditions. Their account would be automatically deducted by the FI of the creditor and eventually paid to the factor supplier, vide Error! Reference source not found.. Similarly, when the farmer is paid against their production, creditor would be automatically repaid with interest through automated calls for repayment. Automated repayment of credit immediately after obtaining payment from the buyer is to make agricultural credit relatively riskfree.

Table 5. Closing of accounts

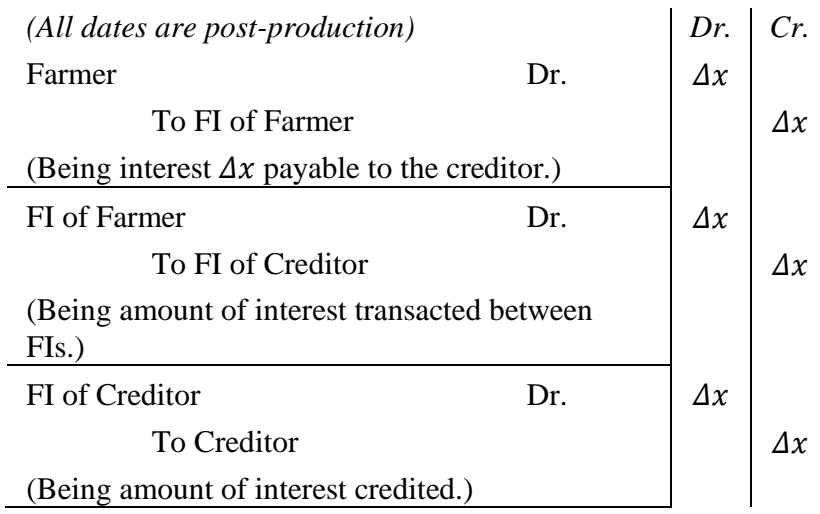

\subsection{Insurance}

Some risks like flood, fire, etc. can only be insured [40], [41]. Insurance of production plans - the insurer being a supplier is chosen on the basis of competitive quotes - should cover all goods so long as they are in production. Thus, if a supplier fails along with redundant suppliers, residual risks [42] may be covered. However, premium of such risks may be borne by the supplier concerned. It should also cover shortfall of quality or quantity of production through insurable conditions. FE should store and provide all necessary data to facilitate insurance.

\subsection{Consultants}

Experts like soil testing labs, agricultural experts, accountants, project managers, doctors, educators, etc. may also be considered among suppliers. They would be responsible for various support services related to farming and ensure, to some extent, that the farmer does not default due to any controllable reason.

\section{LEGAL AND ENFORCEMENT FRAMEWORK}

Success of FE may depend on separate legal and enforcement framework around it. One reason is inordinate delay in Indian legal processes [43]. Then, the nature of the exchange, which is contemplated paperless and depend completely on electronic documents, may require new laws. Moreover, multi-party contracts that exist only electronically may need legal sanctity. FE may not encourage exclusive trade, for which commodity exchanges are appropriate, vide footnote Error! Bookmark not defined.. However, not to put a contract in jeopardy, a player or party to a contract ought to be replaceable by another player who would perform the former's role. Thus, a buyer may be substituted by another buyer or a farmer by another farmer.

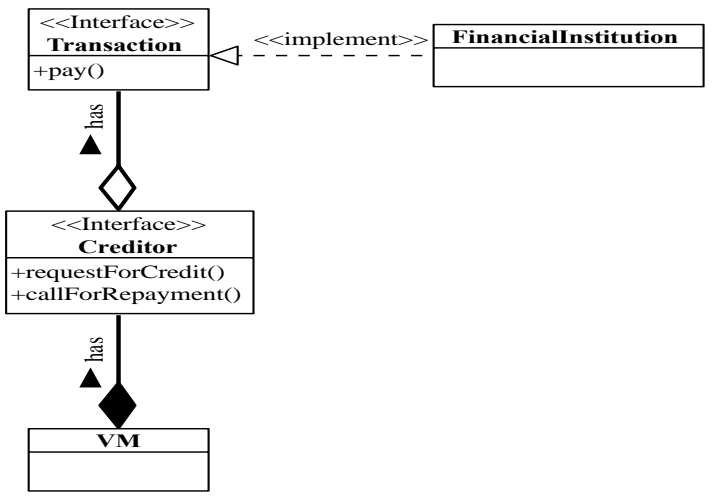

Figure 6: Flow of credit and interest

\section{GOVERNANCE}

An important purpose of $\mathrm{FE}$ is to introduce competition, which is absent in middleman-dominated agriculture market. Governors of FE should promote competitiveness of FE. Apart from new laws mentioned above, mandates and incentives provided by the government in using FE can promote it effectively - after all, without active support by the government, future of FE would be in jeopardy.

\section{CONCLUSION}

$\mathrm{FE}$ is designed to emulate qualities of the middleman that made the latter popular among the farmer. At the same time, it is modeled to overcome non-competition being a major defect of the middleman. Other alternatives such as physical marketplaces created by the Panchayat Raj or commodity exchanges fall short of some of the requirements of the farmer. The former does not facilitate easy loan, local delivery, or hedging. The latter may address speculative risks but not the other two.

The farmer also needs insurance against all kinds of insurable risks and consultants or guides for those that are noninsurable. In other words, risks associated with farming need to be addressed in a well-planned manner and with professional assistance. This aspect, which is not covered by any of the existing infrastructure, is taken care of by FE.

Moreover, rural economy is the birthplace of so-called black money that might land up in financing unlawful activities including terror [44], [45]. An electronic exchange that FE represents can bring in transparency there.

\section{ACKNOWLEDGMENTS}

The first author thanks to Mr. Mulam Venkataramanaiah, RIP, of Gudur, AP, who introduced him to the rudiments of cultivation. He is thankful to Mr. Harish Fabiani, founder of eComServer, Inc., who lent a good ear to him and promoted an online commodities trading exchange. Mr. Gangadhar Heralgi, Co-Founder and CTO of Monocept has reviewed the paper and provided important comments. 


\section{APPENDIX}

\subsection{Calculation of Pearson $\boldsymbol{r}$ Coefficient based on NSSO data}

Table 6. Background data for computation of Pearson $r$ coefficient, vide

Table 1

\begin{tabular}{|c|c|c|c|c|c|c|c|c|c|c|}
\hline States & $\begin{array}{l}\text { Annual } \\
\text { Cultivation } \\
\text { Income }\end{array}$ & $\begin{array}{l}\text { Annual } \\
\text { Total } \\
\text { Income }\end{array}$ & $\begin{array}{l}\text { Annual } \\
\text { Cultivation } \\
\text { Expenditure }\end{array}$ & $\begin{array}{l}\text { Annual } \\
\text { Consumption } \\
\text { Expenditure }\end{array}$ & $\begin{array}{l}(2) \\
(4)\end{array}$ & $\begin{array}{r}-(3) \\
(5)\end{array}$ & $\begin{array}{l}\text {-Incidence o } \\
\text { Indebtedness }\end{array}$ & $\begin{array}{l}\text { of Extent } \\
s \text { Indebtedness }\end{array}$ & $\begin{array}{l}\text { Share } \\
\text { of annual } \\
\text { sincome } \\
\text { from } \\
\text { agriculture }\end{array}$ & $\begin{array}{l}\text { of } \\
\text { Return from } \\
\text { agriculture } \\
\text { e }\end{array}$ \\
\hline (1) & (2) & (3) & (4) & (5) & (6) & (7) & (8) & (9) & $\begin{array}{l}(10)=(2) \\
(3)\end{array}$ & $\begin{array}{l}\div(11)=[(2) \\
-(4)] \div(4)\end{array}$ \\
\hline$\overline{\mathrm{AP}}$ & 8016 & 19608 & 12085 & 28632 & -4069 & -9024 & 82 & 23965 & $41 \%$ & $-34 \%$ \\
\hline Assam & 21504 & 37932 & 3370 & 32588 & 18134 & 5344 & 18.1 & 813 & $57 \%$ & $538 \%$ \\
\hline Bihar & 10152 & 21720 & 6809 & 29508 & 3343 & -7788 & 33 & 4476 & $47 \%$ & $49 \%$ \\
\hline Gujarat & 13968 & 32208 & 11456 & 37524 & 2512 & -5316 & 51.9 & 15526 & $43 \%$ & $22 \%$ \\
\hline Haryana & 17928 & 34584 & 18270 & 52968 & -342 & -18384 & 53.1 & 26007 & $52 \%$ & $-2 \%$ \\
\hline JK & 29112 & 65856 & 6342 & 49308 & 22770 & 16548 & 31.8 & 1903 & $44 \%$ & $359 \%$ \\
\hline Karnataka & 15192 & 31392 & 10344 & 31296 & 4848 & 96 & 61.6 & 18135 & $48 \%$ & $47 \%$ \\
\hline Kerala & 13440 & 48048 & 7793 & 51000 & 5647 & -2952 & 64.4 & 33907 & $28 \%$ & $72 \%$ \\
\hline MP & 11952 & 17160 & 8886 & 28088 & 3066 & -10928 & 50.8 & 14218 & $70 \%$ & $35 \%$ \\
\hline Maharashtra & 15156 & 29556 & 10793 & 32268 & 4363 & -2712 & 54.8 & 10973 & $51 \%$ & $40 \%$ \\
\hline Orissa & 4032 & 12744 & 3143 & 20364 & 889 & -7620 & 47.8 & 5871 & $32 \%$ & $28 \%$ \\
\hline Punjab & 33864 & 59520 & 25945 & 58080 & 7919 & 1440 & 65.4 & 41576 & $57 \%$ & $31 \%$ \\
\hline Rajasthan & 4308 & 17976 & 7668 & 39456 & -3360 & -21480 & 52.4 & 18372 & $24 \%$ & $-44 \%$ \\
\hline Tamil Nadu & 7908 & 24864 & 8597 & 30072 & -689 & -5208 & 74.5 & 23963 & $32 \%$ & $-8 \%$ \\
\hline $\begin{array}{l}\text { Uttar } \\
\text { Pradesh }\end{array}$ & 10032 & 19596 & 9151 & 34788 & 881 & -15192 & 40.3 & 7425 & $51 \%$ & $10 \%$ \\
\hline West Bengal & 8844 & 24948 & 8429 & 32016 & 415 & -7068 & 50.1 & 5237 & $35 \%$ & $5 \%$ \\
\hline All India & 11628 & 25380 & 8791 & 33240 & 2837 & -7860 & 48.6 & 12585 & $46 \%$ & $32 \%$ \\
\hline
\end{tabular}

$(*)$ The original table compiled from NSSO data is col (1) - (9) [22]. Next two columns are calculated. All monetary figures are in Indian rupee.

From column-pairs $(8,10),(8,11),(9,10)$, and $(9,11)$ of Error! Reference source not found., Pearson $r$ coefficient was calculated by means of the following formula: $r=\frac{n\left(\sum x y\right)-\left(\sum x\right)\left(\sum y\right)}{\sqrt{\left[n \sum x^{2}-\left(\sum x\right)^{2}\right]\left[n \sum y^{2}-\left(\sum y\right)^{2}\right]}}$, where $n=16$ (number of states) and $(x, y)$ represents values in column-pairs stated before. 


\subsection{Calculation of Probability of \\ Handsome Returns To The Farmer}

Using conditional probability ${ }^{14}$, let $\chi_{0}$ be the accuracy-factor, in general, of the farmer's Far $^{15}$ consideration, vide use case 1 of Figure 1. If the particular accuracy-factor in considering impacts of land Lan, weather Wea and market Mar be $\chi_{1}, \chi_{2}, \chi_{3}$, respectively, then

$$
\begin{array}{ll}
\text { (4) } & \operatorname{Pr}(\text { Lan } \cap \text { Far })=\operatorname{Pr}(\text { Far }) \operatorname{Pr}(\text { Lan } \mid \text { Far })=\chi_{0} \chi_{1} \\
\text { (5) } & \operatorname{Pr}(\text { Wea } \cap \text { Far })=\operatorname{Pr}(\text { Far }) \operatorname{Pr}(\text { Wea } \mid \text { Far })=\chi_{0} \chi_{2} \\
\text { (6) } & \operatorname{Pr}(\text { Mar } \cap \text { Far })=\operatorname{Pr}(\text { Far }) \operatorname{Pr}(\text { Mar } \mid \text { Far })=\chi_{0} \chi_{3}
\end{array}
$$

Assuming $\chi_{j}=\chi \forall j$, one may write ${ }^{16}$

$$
\operatorname{Pr}(\text { Lan })=\operatorname{Pr}(\text { Wea })=\operatorname{Pr}(\text { Mar })=\chi^{2}
$$

where $\operatorname{Pr}(X)$ is the shorthand for $\operatorname{Pr}(X \cap F a r)$ in the earlier equations, $X$ being one of Lan, Wea, Mar.

Land, weather, and market may, in turn, have influence $\chi_{4}=\chi$ to determine the crop Cro, whereby, following the above notation

$$
\operatorname{Pr}(\text { Cro })=\chi \chi^{2} \chi^{2} \chi^{2}=\chi^{7}
$$

Similarly

(9)

\section{REFERENCES}

[1] A. Maddison, The world economy volume 1: A millennial perspective volume 2: Historical statistics. Academic Foundation, 2007.

[2] K. A. Manikumar, A Colonial Economy in the Great Depression, Madras (1929-1937). Orient Blackswan, 2003.

[3] M. Gandhi and D. Dalton, Gandhi: Selected Political Writings. Hackett Publishing, 1996.

[4] S. Fitzpatrick, The Russian Revolution. Oxford University Press, 2008.

[5] R. K. Sah and J. E. Stiglitz, "The economics of price scissors," Am. Econ. Rev., pp. 125-138, 1984.

[6] P. Milgrom, "Auctions and bidding: A primer," $J$. Econ. Perspect., pp. 3-22, 1989.

[7] P. R. Milgrom and R. J. Weber, "A theory of auctions and competitive bidding," Econom. J. Econom. Soc., pp. 1089-1122, 1982.

${ }^{14}$ Formula: $\operatorname{Pr}(A \mid B)=\frac{\operatorname{Pr}(B \cap A)}{\operatorname{Pr}(B)}[46]$

15 The first three letters of an entity has been taken as its abbreviation.

${ }^{16}$ This assumption is only to simplify computations.
[8] F. Gul and E. Stacchetti, "The English auction with differentiated commodities," J. Econ. Theory, vol. 92, no. 1, pp. 66-95, 2000.

[9] C. D. Hall, "A Dutch auction information exchange," J. Law Econ., pp. 195-213, 1989.

[10] R. Comment and G. A. Jarrell, "The relative signalling power of Dutch-auction and fixed-price self-tender offers and open-market share repurchases," J. Finance, vol. 46, no. 4, pp. 1243-1271, 1991.

[11] L. L. Johnson, "The theory of hedging and speculation in commodity futures," Rev. Econ. Stud., pp. 139-151, 1960 .

[12] T. R. Bielecki and M. Rutkowski, Credit risk: modeling, valuation and hedging. Springer Science \& Business Media, 2002.

[13] W. A. Mauer and T. H. Naylor, "MonopolisticMonopsonistic Competition: The Multi-Product, MultiFactor Firm," South. Econ. J., pp. 38-43, 1964.

[14] H. R. Varian, Microeconomic Analysis. W.W. Norton, 1992.

[15] A. L. Booth and P. Katic, "Estimating the Wage Elasticity of Labour Supply to a Firm: What Evidence is there for Monopsony?*," Econ. Rec., vol. 87, no. 278, pp. 359-369, 2011

[16] J. Kalagnanam and D. C. Parkes, "Auctions, bidding and exchange design," in Handbook of Quantitative Supply Chain Analysis, Springer, 2004, pp. 143-212.

[17] D. P. Bertsekas, D. A. Castanon, and H. Tsaknakis, "Reverse auction and the solution of inequality constrained assignment problems," SIAM J. Optim., vol. 3, no. 2, pp. 268-297, 1993.

[18] M. Martin, S. Kakde, V. A. Kendra, and I. Mumbai, From Debt Trap to Death Trap: Victims of'free'Market an Enquiry Into Farmers' Suicide. Vikas Adhyayan Kendra, 2006.

[19] M. P. Thompson, C. Ho, and J. B. Kingree, "Prospective associations between delinquency and suicidal behaviors in a nationally representative sample," J. Adolesc. Health, vol. 40, no. 3, pp. 232237, 2007.

[20] J. Cuellar and T. R. Curry, "The prevalence and comorbidity between delinquency, drug abuse, suicide attempts, physical and sexual abuse, and selfmutilation among delinquent Hispanic females," Hisp. J. Behav. Sci., vol. 29, no. 1, pp. 68-82, 2007.

[21] C. P. Barlett and C. A. Anderson, "Bad news, bad times, and violence: The link between economic distress and aggression.," Psychol. Violence, vol. 4, no. 3, p. 309, 2014

[22] G. Booch, J. Rumbaugh, and I. Jacobson, The unified modeling language user guide. Pearson Education India, 1999

[23] D. Binkley, M. Davis, D. Lawrie, and C. Morrell, "To camelcase or under_score," in Program Comprehension, 2009. ICPC'09. IEEE 17th International Conference on, 2009, pp. 158-167.

[24] A. Narayanamoorthy, "State of India's farmers," Econ. Polit. Wkly., pp. 471-473, 2006. 
[25] “Pearson's r Correlation (modified from Instructor's Resource Guide for the Text).".

[26] Y. V. Reddy, "Indian Agriculture and Reform: Concerns, Issues and Agenda," INDIAN J. Agric. Mark., vol. 15, no. 1, pp. 1-9, 2001.

[27] A. R. Desai, Social Background Of Indian Nationalism (6Th-Edn). Popular Prakashan, 2005.

[28] P. Oldenburg, "Middlemen in third-world corruption: implications of an Indian case," World Polit., vol. 39, no. 04, pp. 508-535, 1987.

[29] M. Long, "Interest rates and the structure of agricultural credit markets," Oxf. Econ. Pap., pp. 275$288,1968$.

[30] DAWN, "Can the role of middleman be eliminated? Agriculture Corner," 02-Feb-2011.

[31] National Agricultural Cooperative Society, "National Agricultural Policy,” 28-Jul-2000.

[32] Tata Institute of Social Sciences, Rural Campus, "Causes of Farmer Suicides in Maharashtra:AN ENQUIRY Final Report Submitted to the Mumbai High Court,” Mar. 2005.

[33] P. Das, "A Symbolic Approach to Project Management," presented at the PMI Research Conference, Montreal, CA, 2006.
[34] Introduction To Statistical Quality Control, 4Th Ed.

[35] L. A. Zadeh, "Probability measures of fuzzy events," $J$. Math. Anal. Appl., vol. 23, no. 2, pp. 421-427, 1968.

[36] O. Ashenfelter, "How auctions work for wine and art," J. Econ. Perspect., pp. 23-36, 1989.

[37] E. E. Spicer, E. C. Pegler, and W. W. Bigg, Spicer and Pegler's Book-keeping and Accounts. H. F. L., 1956.

[38] L. Guiso and T. Jappelli, "Background uncertainty and the demand for insurance against insurable risks," Geneva Pap. Risk Insur. Theory, vol. 23, no. 1, pp. 727, 1998.

[39] P. B. Hazell, "The appropriate role of agricultural insurance in developing countries," J. Int. Dev., vol. 4, no. 6, pp. 567-581, 1992.

[40] B. N. Lehmann, "Residual risk revisited," J. Econom., vol. 45, no. 1, pp. 71-97, 1990.

[41] S. V. Kumar, "Judiciary facing credibility crisis: CJI," The Hindu, Chennai, 20-Aug-2013.

[42] IANS, "Black Money Promotes Terror, Says Modi," The New Indian Express, 21-Nov-2014.

[43] P. Lilley, Dirty dealing: The untold truth about global money laundering, international crime and terrorism. Kogan Page Publishers, 2003 